\title{
Improving Foreign Language Learning by the Mean of Learning Management System: Review of the Literature
}

\author{
Putri Wulandari $^{1}$, Cucuk Wawan Budiyanto ${ }^{1}$ \\ ${ }^{1}$ Sebelas Maret University
}

\begin{abstract}
Due to the advancement in web technologies, learning management systems are becoming involved in various fields of distance education. The computer-facilitated teaching and learning have been enticed audiences for various advantages offered by the management systems. This paper reviews the need for computer-aided language learning that could be accommodated by the feature-rich learning management systems. A systematic review over the pool of 450 papers from two established journals in education was conducted. The insight from the reviewed papers, subsequently, was analyzed to construct a proposal on the use of learning management systems to improve foreign language learning. The framework of the systems could potentially enhance the learning experience for the more comfortable learning and better learner management.
\end{abstract}

\section{Keywords: learning management systems; MOOCs; open courseware; distance education; computer aided language learning}

\section{INTRODUCTION}

Foreign language learning is one of the required subjects in all curricula (secondary school, for a bachelor's, master's and doctorate degrees). One of the main goals of foreign language teaching in secondary and higher education is to develop students' foreign language communicative competence in all its complex components (linguistic, sociolinguistic, discourse, sociocultural, strategic) needed for students to communicate in social and professional areas [1]. Actually, in learning of the second language, we are found some problems there. Ellis [2] explained that second language acquisition is a complex process, involving many interrelated factors. The term 'Second Language Acquisition' (SLA) refers to the subconscious or conscious processes by which a language other than the mother tongue is learnt in a natural or a tutored setting. Ellis stressed that there are afective pre requisites to acquisition such as a positive orientation to speakers of the language. Some skills and knowledge, called competence, will be acquired through the input, and certainly, the initial production will not be very accurate. When studying the language for special purposes, one should master a certain set of units of professional vocabulary, learn a large number of terms which allow to express an idea briefly and precisely and know unique concepts necessary for a specialist in his future work. A specific character of a foreign language as an academic subject makes it possible to use computer technologies to the full extent which is especially effective for mastering grammatical and lexical models [3]. 
Taking all the above of some complex problem on foreign language learning, today there is so many research which tries to answer that problem. Teachers should provide the necessary time, space and support to students to make them reflect on the learning strategies that were used and on the way these strategies have influenced students 'learning. If students' experiences have been negative, the teacher should follow a scaffolding approach that moves students progressively to attenuate the impact that those negative experiences have had in their motivation to learning[4]. Teoh, Lin and Belaja [2] in their findings concludes that there are some recommendations for designers and instructors of language learning courses in distance education. The course designers should be aware of the particular needs of the distance learners especially regarding speaking. They also need to consider to increase the number of contact hours via teleconferencing sessions or traveling to regional centers to meet the students and create opportunities for students to learn, interact and seek answers to their queries in the target language. Including the need to guide and motivate students to spend sufficient time on reading and enriching their vocabulary as well as on practicing their communication skills and learning grammar. In the quest to improve the teaching of English language to distance learners; teachers would do well to understand the background and characteristics of their students. They need to understand the students' difficulties, perceptions, and environments. Depend on the specialty of the student the stress in forming speech activities skills can be different as practical knowledge of a specialist has to be as close as possible to the realities of his/her future work. It is, for example, more importantly for IT- specialists to be able to work with applications in English, websites, or reading specialized literature. In contrast to tourism managers' urgent need for an oral communication skill [3].

An important part of the modern society is also the internet and related foreign language sources - blogs, videos, podcasts, wiki, recordings, chat programs, social networks, online games, and exercises. Although not all of them will be used by persons with severe visual impairment, several means can be used in teaching, especially electronic mail and online videos and recordings. The present research focuses on the area of teaching foreign languages[5].

Despite the vast amount of research addressing the language learning, the proposed solution may not be adequate to solve the entire problems faced by the community. So, that solution not fits at all condition. Moreover, when today is a digitalization mode and all of the fields in the world, influence of that.

Nowadays, the technological developments taking place in the world and make all areas influence of its. Education as an example, technological advances make education with something that full of digitalization. Due to that phenomenon, especially in web technologies development on education, learning management systems are becoming involved in various fields of distance learning. With learning management systems, learning experience potentially enhances the more comfortable learning and better learner management. The learner can more active on doing the learning well because learning management system makes learner as a focused of learning, not a teacher. Incentered teaching processes is repeatedly emphasized, individuals are expected to reach information; use the information by interpreting, and they are also supposed to put forward new information in the light of available information. Individuals should be aware of how they learn to become equipped with these features [6]. In fact, among all definitions given to LMSs by various researchers and specialists into the domain, the one provided by Berking and Gallagher defined LMSs as "... a key enabling technology 
for "anytime, anywhere" access to learning content and administration" [7]. Therefore, motivation

it will be interesting to explore further on the potential contribution of learning management systems to language learning.

The paper seeks to contribute to the literature by suggesting the strategy to improve the performance of distance education learners. Specific questions to be explored are the answers to the following:

- What are the advantages of adopting LMS in the computer-assisted language learning classroom?

- How the use of LMS contributes to solving the problems in foreign language learning?

- To what extent do LMSs improve foreign language learning in distance education?

The rest of the paper is structured as follows: In the next section, the strategy of conducting a review of the literature is elaborated. The findings extracted from the examination of the literature are suggested in the third section. The discussion upon the finding and the proposed strategies on the improving foreign language learning with the mean of learning management systems are suggested in the next section. In the final section, the paper is concluded.

\section{RESEARCH METHOD}

This article adopted a literature review approach suggested by Okoli and Schabram [8]. The literature review was conducted on the journals in distance education. The following keywords were utilized: 'learning management systems,' 'MOOCs,' 'open courseware,' 'distance education,' and 'Computer Assisted Language Learning (CALL).' Two main journals were reviewed comprise the CALL journal and The Turkish Online Journal of Distance Education. Relevant articles from several conference proceedings also examined. Articles reviewed are within the period 2012 2017 or within five years period.

Total papers studied were 5 and 14 from the CALL journal and TODJE respectively. As a comparison, 14 papers published in the Procedia of Social Behavioral Science between 2013 and 2017 also reviewed. In order to construct a comprehensive understanding of the subject, a matrix of concept was built focuses on the use of LMS for foreign language in distance learning. The number of articles reviewed along with the relevant articles obtained in the search were depicted in Figure 1. 


\section{Chart of Relevant Paper on Literature Review}



Article / Journal between

2012 - 2017

-CALL $\square$ TODJE Other

Figure 1. Papers reviewed in the study

\section{LITERATURE REVIEW}

\section{The use of Technology in foreign language learning}

Well-established technologies, such as the personal computer and internet access, have become nearly ubiquitous for foreign language (FL) learning in many industrialized countries. Also, relatively new technologies, such as smartphones and other mobile internet-accessible devices, are increasingly available [9]. The paper summarized the technologies employed for foreign language learning as represented in Table I below.

TABLE I. TECHNOLOGY FOR FOREIGN LANGUAGE LEARNING

\begin{tabular}{|c|c|c|}
\hline Technology & Definition & $\begin{array}{l}\text { Example affordances for } \\
\text { the language study }\end{array}$ \\
\hline \multicolumn{3}{|l|}{$\frac{\frac{\text { Schoolhouse- }}{\text { or classroom- }}}{\underline{\text { based }}}$} \\
\hline $\begin{array}{c}\text { Course } \\
\text { management } \\
\text { system } \\
(\mathrm{CMS})\end{array}$ & $\begin{array}{l}\text { The server-based application } \\
\text { used to present materials and } \\
\text { services required for blended or } \\
\text { distance learning (such as } \\
\text { syllabi, required readings, } \\
\text { calendars, etcetera.). Teachers } \\
\text { and students access a CMS over } \\
\text { a network through a web } \\
\text { browser, using a menu-driven } \\
\text { interface }\end{array}$ & $\begin{array}{l}\text { Enable sharing of course } \\
\text { materials, allowing access } \\
\text { to content anytime, } \\
\text { anywhere } \\
\text { Facilitate course content } \\
\text { organization and teacher- } \\
\text { student and student-- } \\
\text { student communication }\end{array}$ \\
\hline
\end{tabular}


TABLE I, CONT.

Interactive

white board

Portfolio

Individual study tools

Electronic A dictionary in electronic form dictionary - either handheld or online

A collection of authentic language in spoken form, written form, or both. Corpora Corpus vary regarding design (fixed size vs. expandable), content (general vs. specialized), and medium (written vs. spoken)
Promote interactive activities and engage students and teachers in collaborative work Enhance motivation and improve attitudes toward learning Incorporate authentic content available on the the internet into the classroom lessons

Support learner autonomy and self-assessment Emphasize the process of learning, rather than just the products of learning Facilitate setting learning goals, monitoring progress, and developing selfassessment skills [10]

Provide access to rich, authentic input. Enable broad access to linguistic data Promote data-driven inductive learning [11].

Speed searches for a lexical item so that looking up words does not greatly interrupt the reading process. Accommodate different look-up preferences and learning styles

Support individualized and elaborated input 
TABLE I, CONT.

A method of reference, usually in the form of a hyperlink, that

Electronic gloss or annotation

Intelligent tutoring system

Grammar checker

Automatic speech recognition (ASR) and pronunciation program allows learners to access glosses (word- or sentence-level, context-specific translations) or annotations (explanatory or background information) while reading an electronic text

A program that simulates a tutor by providing direct, customized instruction and feedback to a learner. Such a system is generally comprised of four components: an interface (platform), an expert model (domain of knowledge the student is intended to acquire), a student model (current state of student's knowledge), and a tutor model (which provides appropriate feedback and instruction by using the identified gaps between the student and the expert models)

A program designed to evaluate a written text's well-formedness regarding grammaticality. Such programs are often packaged, along with spell checkers, within word processing programs

A technology that allows a computer to identify the words a person speaks into a microphone. ASR is often a component of speech pronunciation software, and as such, identifies particular parameters of the learner's output, such as prosody or specific sounds, and provides feedback on these aspects of performance
Provide for efficient lookup of unknown words and multimedia capability Facilitate reading comprehension, and incidental and intentional vocabulary learning

Tailor instruction to the individual learner

Provide immediate, specific feedback in a systematic manner Can implement task based interfaces in language instruction

Identify/flag low-level morphosyntactic errors [12].

Provide students with immediate input and feedback

Compare student's pronunciation acoustically with a target pronunciation and provide feedback Provide learner with an opportunity to work on speaking ability individually, at selfselected pace Allow learner to practice simulated dialogue with computerized agent 
TABLE I, CONT.

\section{Network- based social computing \\ Virtual world or serious game \\ A virtual world is a program that allows learners to move a representation of a character, or “'avatar', through a 3-D graphical environment. A serious game is a virtual environment or traditional computer game in which activities are guided or restricted by the program and users have a specified goal or set of goals to complete}

Chat computer-mediated
communication; either textbased
or include audio

Social networking
A form of synchronous communication; either textbased or include audio

Social networking, of which Facebook and MySpace are the best-known examples, enables peer-to-peer communication and collaboration. Users develop their own presence on social networking by creating profile pages about themselves, and then joining networks based on geography, interests, associations, or friendships

A web application that displays entries authored by the blog owner with time and date stamps and is visible to other web users
Provide virtual meeting spaces

Enable learner to navigate within simulated environments, including those modeled after target language locales and incorporating culturally relevant objects

Encourage role play through the ability to embody different characters within a scenario

Record logs of interactions, which can be printed for review and used as an assessment tool [13]. Enable communication and collaboration among students or between students and native speakers without constraints of distance or location

Support networking among users as well as the ability to communicate with others with similar interests Enable interaction with native speakers and other students of the target language

Allow for synchronous and asynchronous

communication

Support personal journaling or blogging and enable feedback in the form of comments on blog posts Encourage collaborative learning 
TABLE I, CONT.

An asynchronous system in

Internet

forum or

message

board

Wiki

\section{Mobile and} portable devices

Tablet PC or PDA which messages are sent to multiple recipients. Messages are threaded according to topic and a notification is often sent to a user's e-mail address when an update is posted

A website that allows multiple users to post or edit information

A tablet personal computer (tablet PC) is a portable personal computer with a touchscreen. A personal digital assistant (PDA) is a hand-held mobile computing device that combines many features now common to other mobile devices: a calendar, contacts list, word processing, and depending on the OS, applications, such as Excel, PowerPoint, and Adobe Reader

A portable media player produced by Apple, Inc. It can also serve as external data storage devices with a wide range of memory capacities. iPods can be used to play downloaded television shows and movies and have a small screen for viewing this media. Podcasts, or audio and video digital-media files, can also be downloaded for use with the iPod or other digital media player
Organize discussions via topic thread Enable online information exchange without constraints of time and distance

Help students and instructors to find information easily through organization by topic Enable collaboration on inclass projects Support open-editing of content

Enable handwritten computer input in target language scripts Capture diagrams and illustrations digitally Run software for language learning on portable device

Serve as a portable hard drive for data upload and download Enable rich input through language-learning podcasts and broadcasts of authentic speech

Enable students to record speech samples or homework activities digitally, and upload these for teacher or peer review 
TABLE I, CONT.

\begin{tabular}{|cll|} 
& $\begin{array}{l}\text { A cell phone is a mobile } \\
\text { telephone, and a smartphone is a } \\
\text { mobile phone with advanced } \\
\text { capabilities, and often, PC-like } \\
\text { functionality. A smartphone } \\
\text { smartphone } \\
\text { often has a keyboard or other } \\
\text { text entry functionality, the } \\
\text { internet and email abilities, and } \\
\text { the capacity to run an operating } \\
\text { system and related software }\end{array}$ & $\begin{array}{l}\text { Patities that utilize text } \\
\text { messaging, and sharing and } \\
\text { taking pictures }\end{array}$ \\
$\begin{array}{l}\text { Facilitate teacher-student } \\
\text { and student-student } \\
\text { communication during } \\
\text { remote learning activities } \\
\text { access }\end{array}$ \\
\hline
\end{tabular}

A large number of studies confirmed that learners enjoy using technology in FL learning and that they prefer using technology over more traditional methods and materials. Because of technology, learners tend to be more engaged in the process of learning, and have a more positive attitude towards learning [9].

\section{CALL}

Computer-assisted language learning (CALL) has been a subject of investigation for over 30 years, yet the state of the CALL literature leaves much to be desired regarding a unified research agenda and durable, validated findings [9]. It is argued that the common problems in CALL research include the poor description of the research design and poor choice of variables to be investigated. Let alone the lack of relevant data about participants, studies based on inexperienced users of the technology, and a nearly exclusive focus on Western European languages; The situation creates a challenge for foreign language pedagogy and Second Language Acquisition (SLA) researchers attempting to evaluate the efficacy of technology use in FL learning and teaching.

\section{The use of LMS in CALL}

Nowadays most of the universities, institutes, colleges, and schools implement elearning technology as an integral part of their learning systems and a part of our dayto-day lives. It helps to enhance their traditional learning systems and to use an alternative approach to learning. Due to the almost unlimited power of the internet, virtual classrooms make the learning process much easier. E-learning can be defined as a learning process based on digitally delivered content, services and tutoring support which is an alternative to traditional education featured as personalized and collaborative learning involving a community of learners, teachers, facilitators, and experts [14]. Since the early days of e-Learning, Learning Management Systems (LMS), Learning Content Management System (LCMS), Learning Design System (LDS), and Learning Support System (LSS) are becoming more and more usual words and the key driving products on the market. The educational market, in particular, conceived the valuable tools as compressing the time required to develop learning 
content. Through the use of learning objects, the technology provides targeted learner focused learning, shortening the time of acquiring necessary skills [14].

LMS successfully connects students with their fellow students and their instructors. Such ability extends classroom activities online and empowering internet sharing of information, research materials, and library resources. E-learning language courses for higher education based on LMS encourage teachers to use a broad range of delivery and instructional methods in a computer-based learning environment. Learning tools such as presentation, audio and animated demonstration, discussion and debate, tutorial, gaming, role-playing, simulation, cooperative and collaborative learning are increasingly popular. For example, a discussion forum could enhance speaking skills and collaborative learning since online forums reduce physical and psychological barriers. According to Ushakov [14], online discussion forums does not merely motivate learners to speak, but also encourages those who are shy and withdrawn to be more courageous and willing to participate". It also "provides them with a nonthreatening environment that reduces their anxiety and concerns about being embarrassed if they were to speak face-to-face in front of the public". In this regard, LMS creates an environment for fostering communicative skills of students, transforms pedagogical interaction into the new effective learning process.

The most important points to be underlined are the presentation of features or technologies in foreign language learning as mentioned in Table II integrated within the LMSs. It is also important to be improved the LMS feature so that it can work optimally in support of the improvement of foreign language learning in distance education. According to Watson and Watson [15], LMSs can be distinguished from other Information Systems for several characteristics.

TABLE II. FEATURES ADDRESSED BY LMS

(REPRODUCED FROM WATSON AND WATSON[15] )

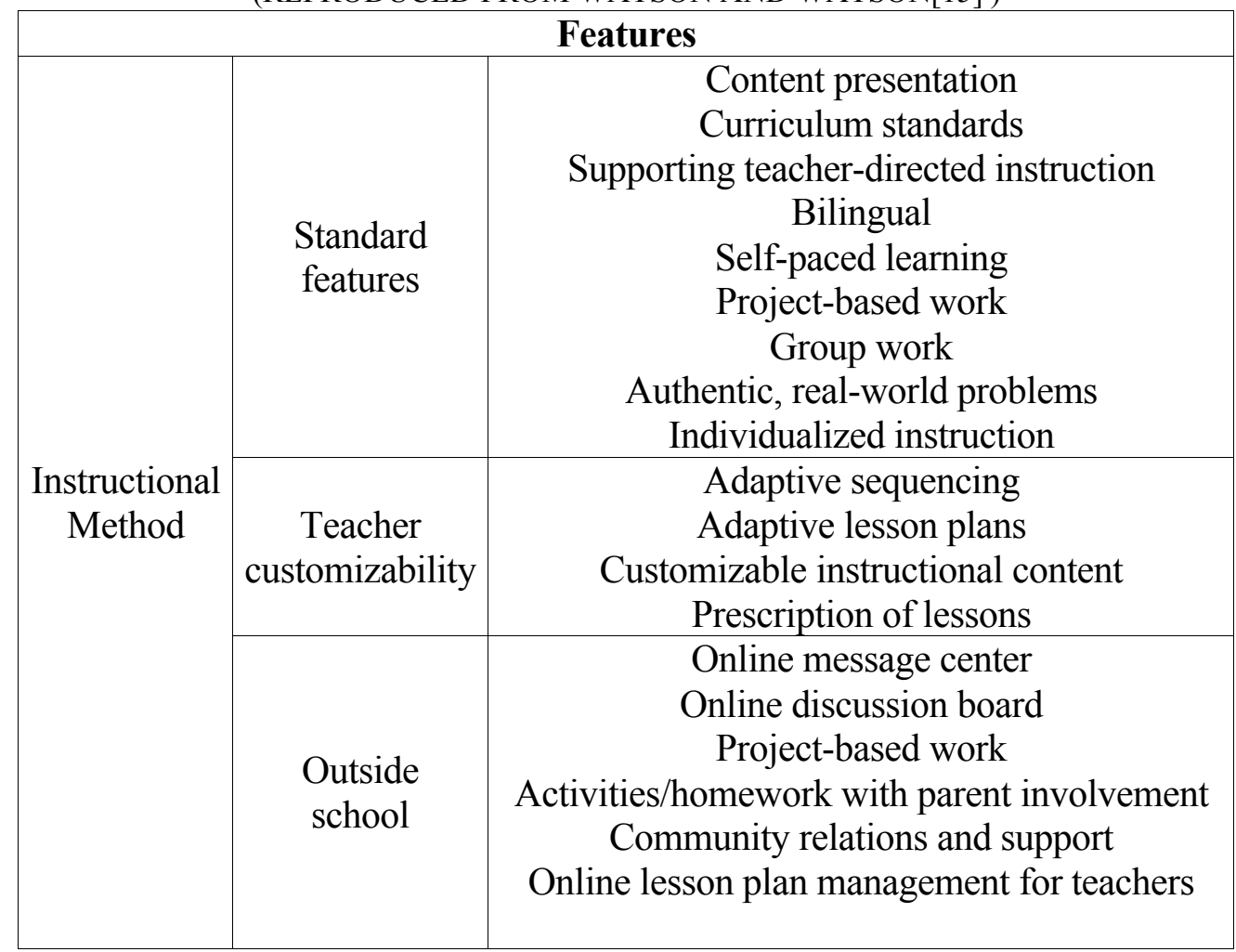


TABLE II, CONT.

\begin{tabular}{|c|c|}
\hline \multirow{5}{*}{ Data management } & Attendance \\
Health information \\
Parent/guardian information \\
Enrollment \\
Class schedule \\
Record of attainments mastered \\
Mastery progress \\
\hline Pssessment & Post-test/Pre-test \\
& Formative tests \\
Practice tests \\
Diagnostic tests \\
Mastery-level tests \\
\hline Reporting & Summative test report to teachers/parents \\
& Formative test report to teachers/parents \\
& Student information report to teachers/parents \\
& Record of attainments report to teachers/parents \\
& Mastery progress report to teachers/parents \\
& Customizable reporting for teachers \\
\hline
\end{tabular}

\section{ANSWERING RESEARCH QUESTION AND DISCUSSION}

\section{The advantages of adopting LMSs in the computer-assisted language learning.}

Teoh, Lin, and Beraja [2] identified that learners of foreign language face eight aspects of language. Speaking remains the top challenge faced by learners. Grammar, vocabulary, and writing are the following abilities learners have to master. Overcoming those problems would likely diminish the main barriers to language learning.

As the key players in language learning, learners are required to be more actively communicate with the other members of the educational community [16]. Therefore the distance learning courses have to be designed to build lively interaction. Online courses should not only be individually-oriented, personalized and context-aware to answer learners' specific needs but they ought to be collaboratively-oriented to enrich the social, communicative and interactive abilities of the participants.

It is when the capabilities of LMSs come into perspective. Teachers are encouraged to employ LMSs outside of the schools to extend the learning environment to the home and further [15]. The use of LMSs in foreign language teaching facilitated innovative delivery instruction such as flipped classroom [4]. The strategy to extend classroom hours enable teachers to focus on successfully addressing all subjects in the curriculum. The non-stop connection between teachers, students, and the learning material can only be achieved by introducing LMSs in the delivery.

A LMS-facilitated learning environment transforms classrooms into interactive and dynamic places where teachers facilitate the students in their learning [17]. The constructivist-based instruction focuses on flexible and learner-defined goals, and, more importantly, better address personalized assessment [15]. When student's motivation and attitude is taken into consideration, the readiness for autonomy in language learning 
drives the motivation levels are higher than those of traditional in-class education [18]. It is understood since distance learners must regulate and oversee the rate and direction of their learning to a much greater degree than classroom learners.

The potential ability of the use of LMS to address the challenges in language learning.

The features of LMSs would be beneficial to resolve the problems in foreign language learning in distance education. Eight challenges faced by foreign language learners in distance learning namely speaking, vocabulary, grammar, writing, spelling, pronunciation, reading, and listening [2]. The examination of the literature exemplifies the potential abilities of LMSs to overcome the challenges. The problems listed in the table are derived from Teoh, Lin [2] exploration in distance learning. The proposed solutions were synthesized from Watson and Watson [15] work on LMSs characteristics.

TABLE III. LMSS AS THE PROPOSED SOLUTION FOR DISTANCE LEARNING PROBLEMS.

\begin{tabular}{|c|c|c|}
\hline Problems & Solution with LMS & Justification \\
\hline $\begin{array}{l}\text { (Speaking) 'I } \\
\text { cannot speak } \\
\text { fluently in } \\
\text { English' }\end{array}$ & $\begin{array}{l}\text { Supporting teacher- } \\
\text { directed instruction, } \\
\text { Customizable instructional } \\
\text { content, and Online } \\
\text { discussion board with } \\
\text { supporting Intelligent } \\
\text { tutoring system and } \\
\text { Automatic speech } \\
\text { recognition (ASR) and } \\
\text { pronunciation program }\end{array}$ & $\begin{array}{l}\text { Compare student's pronunciation } \\
\text { acoustically with a target } \\
\text { pronunciation and provide } \\
\text { feedback } \\
\text { Provide learner with an } \\
\text { opportunity to work on speaking } \\
\text { ability individually, at a self- } \\
\text { selected pace } \\
\text { Allow learner to practice } \\
\text { simulated dialogue with } \\
\text { computerized agent } \\
\text { Tailor instruction to the individual } \\
\text { learner } \\
\text { Provide immediate, specific } \\
\text { feedback in a systematic manner } \\
\text { Can implement task based } \\
\text { interfaces in language instruction }\end{array}$ \\
\hline $\begin{array}{c}\text { (Vocabulary) 'I } \\
\text { find it difficult to } \\
\text { express what I } \\
\text { want to say } \\
\text { because of my } \\
\text { limited } \\
\text { vocabulary.' }\end{array}$ & $\begin{array}{l}\text { Supporting teacher- } \\
\text { directed instruction, } \\
\text { Customizable instructional } \\
\text { content, and Self-paced } \\
\text { learning with supporting } \\
\text { Electronic dictionary }\end{array}$ & $\begin{array}{l}\text { Speed searches for a lexical item } \\
\text { so that looking up words does not } \\
\text { greatly interrupt the reading } \\
\text { process. Accommodate different } \\
\text { look-up preferences and learning } \\
\text { styles } \\
\text { Support individualized and } \\
\text { elaborated input content available } \\
\text { on the internet into classroom } \\
\text { lessons }\end{array}$ \\
\hline
\end{tabular}


TABLE II, CONT.

\begin{tabular}{|c|c|c|}
\hline $\begin{array}{l}\text { (Grammar).' I } \\
\text { fare badly in } \\
\text { sentence making } \\
\text { because of my } \\
\text { poor grammar.' }\end{array}$ & $\begin{array}{l}\text { Supporting teacher- } \\
\text { directed instruction, } \\
\text { Customizable instructional } \\
\text { content, any Assesment, } \\
\text { and Self-paced learning } \\
\text { with supporting Electronic } \\
\text { dictionary }\end{array}$ & $\begin{array}{l}\text { Identify/flag low-level } \\
\text { morphosyntactic errors } \\
\text { (Burston, 2001; Jacobs \& } \\
\text { Rogers, 1999) } \\
\text { Provide students with } \\
\text { immediate input and } \\
\text { feedback }\end{array}$ \\
\hline $\begin{array}{c}\text { (Writing) 'I find } \\
\text { it difficult to } \\
\text { write in } \\
\text { English.' }\end{array}$ & $\begin{array}{l}\text { Supporting teacher- } \\
\text { directed instruction, } \\
\text { Customizable instructional } \\
\text { content, any Assesment, } \\
\text { Project-based work, and } \\
\text { Self-paced learning with } \\
\text { supporting Blog or writing } \\
\text { space }\end{array}$ & $\begin{array}{l}\text { Support personal journaling } \\
\text { or blogging and enable } \\
\text { feedback in the form of } \\
\text { comments on blog posts } \\
\text { Encourage collaborative } \\
\text { learning }\end{array}$ \\
\hline $\begin{array}{l}\text { (Spelling)' I } \\
\text { have many } \\
\text { spelling } \\
\text { mistakes in my } \\
\text { writing.' }\end{array}$ & $\begin{array}{l}\text { Supporting teacher- } \\
\text { directed instruction, } \\
\text { Customizable instructional } \\
\text { content, and Online } \\
\text { discussion board with } \\
\text { supporting Intelligent } \\
\text { tutoring system and } \\
\text { Automatic speech } \\
\text { recognition (ASR) and } \\
\text { pronunciation program }\end{array}$ & $\begin{array}{l}\text { Compare student's } \\
\text { pronunciation acoustically } \\
\text { with a target pronunciation } \\
\text { and provide feedback } \\
\text { Provide learner with an } \\
\text { opportunity to work on } \\
\text { speaking ability individually, } \\
\text { at an independent pace. } \\
\text { Allow learner to practice } \\
\text { simulated dialogue with } \\
\text { computerized agent } \\
\text { Tailor instruction to the } \\
\text { individual learner } \\
\text { Provide immediate, specific } \\
\text { feedback in a systematic } \\
\text { manner } \\
\text { Able to implement task } \\
\text { based interfaces in language } \\
\text { instruction. }\end{array}$ \\
\hline
\end{tabular}


TABLE III, CONT.

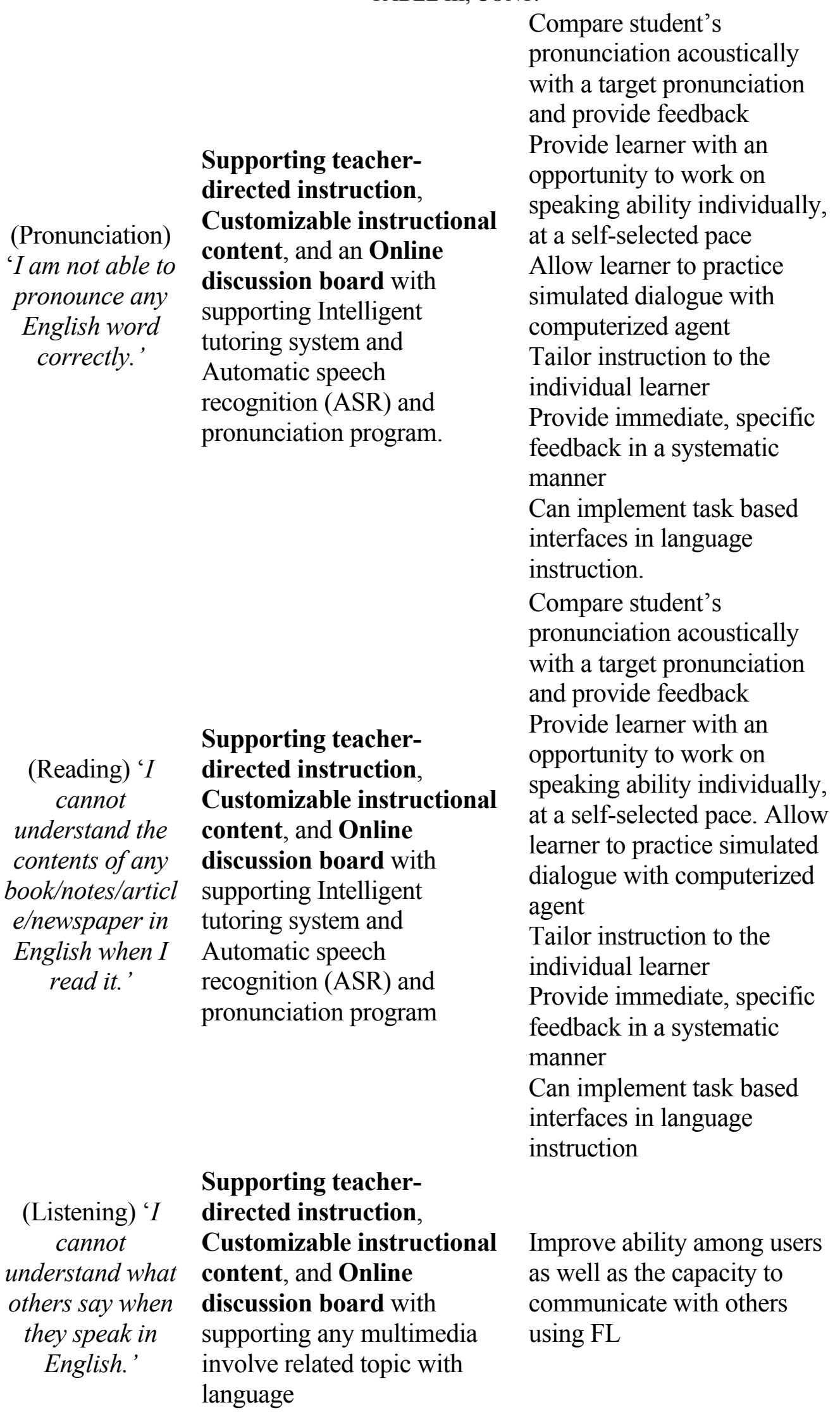




\section{The extent of improvement facilitates by LMS}

According to Ushakov [14], the efficiency of e-learning enabled by the use of LMSs has boosted a high demand for e-learning systems at the higher educational institutions. The figures allure decision makers to adopt LMSs as part of their strategy [19]. The broad range of LMSs based activities and resources need to be contained the university's foreign language modules in order to increase students' interaction with foreign language. Such design is intended to motivate students to work independently enhancing their language and communication skills [20].

The broad range of LMSs based activities and resources need to be activated in the university foreign language modules to increase the time students interact with the language and to motivate them to work independently and thus to promote their language and communication skills, encourage them to become life-long learners. All these seem to be promising practices in FLT in the 21st century. The learners' satisfaction during the courses, emphasizes the perceived quality of the course, teaching materials, and discussion arrangements to be the factors need to be taken into consideration [21].

The LMSs' characteristics of personalized setting[15], however, needs to be activated for the maximum use of the tools. Given individual's learning styles influences the students' language learning performance [6], the course designers should comply with the methodological development guidance. In this regard, electronic course designers are required to carefully design and deveop instructions for students. The design should consider the use of forums and chats are built into the LMSs to encorage students to increase their study duration over the language to improve their overall language proficiencies.

\section{CONCLUSION}

The literature reviewed indicates that LMS will be very helpful in improving the learning of foreign languages in distance education both regarding management of learning and related to the achievement of learning outcomes. LMS offers many features that can be optimized in support of more effective and efficient learning. In optimizing the LMS need the role of educators who understand the needs and characteristics of students so that learning can occur in a comfortable and measurable, especially in distance education.

\section{REFERENCE}

[1] Sysoyev, P.V. and M.N. Evstigneev, Foreign Language Teachers' Competency in Using Information and Communication Technologies. Procedia - Social and Behavioral Sciences, 2015. 200: p. 157-161.

[2] Teoh, G.B.S., A.L.W. Lin, and K. Belaja, WHICH ASPECTS OF THE ENGLISH LANGUAGE DO DISTANCE LEARNERS FIND DIFFICULT? Turkish Online Journal of Distance Education, 2016. 17(3): p. 8.

[3] Dmitrichenkova, S.V., V.A. Chauzova, and E.A. Malykh, Foreign Language Training of IT-students with the Programme "Translator in the Directions and Specialties of Engineering Faculty". Procedia Computer Science, 2017. 103: p. 577-580. 
[4] Basal, A., The Implementation of a Flipped Classroom in Foreign Language Teaching. Turkish Online Journal of Distance Education, 2015. 16(4): p. 10.

[5] Malinovská, O. and L. Ludíková, ICT in Teaching Foreign Languages to Adult People with Acquired Severe Visual Impairment. Procedia - Social and Behavioral Sciences, 2017. 237: p. 311318.

[6] Pepe, K. and M. Kozan, Researching the Foreign Language Learning Styles of Students in Different Departments. Procedia - Social and Behavioral Sciences, 2013. 70: p. 260-266.

[7] Dobre, I., Learning Management Systems for Higher Education - An Overview of Available Options for Higher Education Organizations. Procedia - Social and Behavioral Sciences, 2015. 180: p. 313320.

[8] Okoli, C. and K. Schabram, A Guide to Conducting a Systematic Literature Review of Information Systems Research. Sprouts Working Papers on Informations Systems, 2010. 10(26): p. 49.

[9] Golonka, E.M., et al., Technologies for foreign language learning: a review of technology types and their effectiveness. Computer Assisted Language Learning, 2012. 27(1): p. 70-105.

[10] Blackburn, J.L. and M. Hakel, Enhancing self-regulation and goal orientation with ePortfolios, in Handbook of research on eportfolios, A. Jafari, Editor. 2006, Idea Group Inc. . p. 6.

[11] Bernardini, S., Corpora in the Classroom, in How to Use Corpora in Language Teaching, J.M. Sinclair, Editor. 2004, John Benjamins Publishing Company.

[12] Burston, J., Exploiting the Potential of a Computer-Based Grammar Checker in Conjunction with Self-Monitoring Strategies with Advanced Level Students of French. CALICO Journal, 2001. 18(3): p. 16.

[13] Tudini, V., Using native speakers in chat. Language Learning \& Technology, 2003. 7(3): p. 18.

[14] Ushakov, A., Learning Content Management Systems in Flt: Canadian Experience. International Journal of English Language and Literature Studies, 2017. 6(1): p. 25-32.

[15] Watson, W.R. and S.L. Watson, An Argument for clarity: What are Learning Management Systems, what are they not, and what should they become, in TechTrends January 2007, Research Gate. p. 6.

[16] Garcia-Sanchez, S., Online Metacognitive Tasks for EFL Distance Learners. Turkish Online Journal of Distance Education, 2016. 17(4): p. 14.

[17] Ekmekci, E., The Flipped Writing Classroom in Turkish EFL Context: A Comparative Study on a New Model. Turkish Online Journal of Distance Education, 2017. 18(2): p. 16.

[18] Genc, G., K. Emine, and S. Aydin, A Comparative Study on the Motivation and Attitudes of Language Learners of Online Distance and Traditional in-Classrom Education. . Turkish Online Journal of Distance Education, 2016. 17(4): p. 12.

[19] Parvin, I., A Conceptual Framework of Virtual Interactive Teacher Training through Open and Distance Learning for the Remote Area English Teachers of Bangladesh. Turkish Online Journal of Distance Education, 2017. 18(1): p. 8.

[20] Hubackova, S., Geocaching as a Motivation to Foreign Language Teaching. Procedia - Social and Behavioral Sciences, 2016. 232: p. 321-325.Sun, P.-C., et al., What drives a successful e-Learning? An empirical investigation of the critical factors influencing learner satisfaction. Computers \& Education, 2008. 50(4): p. 1183-1202. 